\title{
IMPLEMENTATION OF COOPERATIVE LEARNING MODEL OF STRUCTURAL APPROACH NUMBERED HEADS TOGETHER TO IMPROVE STUDENTS' MATHEMATICS ACHIEVEMENT IN CLASS VIII.6 SMP NEGERI 16 PEKANBARU
}

\author{
PENERAPAN MODEL PEMBELAJARAN KOOPERATIF \\ PENDEKATAN STRUKTURAL NUMBERED HEADS \\ TOGETHER (NHT) UNTUK MENINGKATKAN \\ HASIL BELAJAR MATEMATIKA SISWA \\ KELAS VIII.6 SMP NEGERI 16 \\ PEKANBARU
}

\author{
Habib Abdullah, Atma Murni, Rini Dian Anggraini \\ Pendidikan Matematika, Universitas Riau \\ Email : abdullah.habib03111995@gmail.com
}

Submitted: (2 Mei 2020); Accepted: (27 Mei 2020);

Published: (31 Mei 2020)

\begin{abstract}
This research was conducted because there are still many student learning outcomes that score below the value minimum mastery criteria (KBM) with a percentage of 10,34\% who achieve the minimum mastery criteria on the associating build flat side space of learning mathematics of class student VIII.6 SMP Negeri 16 Pekanbaru. This research aims to improve the learning process and mathematics learning outcomes by Cooperative learning structured approach Numbered Heads Together. The Classroom Action Research with two cycle, conducted in class VIII.6 SMP Negeri 16 Pekanbaru in the second semester of the 2018/2019 academic year. Research subject as many as 29 students. The research instrument consists of learning devices and instrument data collectors. The learning device consists of Syllabus, Lesson Plan and Worksheet. While The instrument data collector consists of observation sheet and math achievement test. The observation sheet obtained by qualitative descriptive while the test of mathematics learning outcomes obtained by analyzed statistically. The process of learning mathematics in cycle I to cycle II has increased. Percentage of students that reach KBM increase from the basic score, test I, and test II. The number of students who reach Minimum Mastery Criteria on basic score, daily test I and daily test II are respectively (10,34\%), (17,24\%) and (48,27 \%). The conclusion of this research is application of the Cooperative learning structured approach Numbered Heads Together can improve learning process and increase mathematics learning outcomes from the students at class VIII.6 SMP Negeri 16 Pekanbaru in the second semester academic years 2018/2019.
\end{abstract}

Keywords: Mathematics learning outcomes, Cooperative learning, Numbered Heads Together, Classroom action research

\section{PENDAHULUAN}

Matematika merupakan salah satu mata pelajaran yang diajarkan di sekolah. Pembelajaran matematika yang ada di sekolah sangat erat kaitannya dengan permasalahan dalam kehidupan sehari-hari. Melalui pembelajaran matematika, siswa diharapkan mampu menyelesaikan masalah-masalah yang mengandung konsep matematika dengan kemampuan dan pengetahuan yang dimilikinya. Peraturan Menteri Pendidikan dan Kebudayaan
RI Nomor 58 Tahun 2014 menjelaskan bahwa tujuan pembelajaran matematika di sekolah diantaranya adalah agar siswa dapat: (1) mengerti konsep yang ada pada materi matematika; (2) memakai pola untuk membuat prediksi terhadap penyelesaian suatu masalah, dan bisa menyusun kesimpulan yang umum berdasarkan fakta atau data yang tersedia; (3) memakai logika untuk menentukan sifat matematika, mengerjakan manipulasi matematika untuk menyederhanakan dan 
menganalisis elemen matematika yang tersedia guna memecahkan masalah dalam lingkup matematika maupun di luar matematika (kehidupan nyata, IPTEK); (4) menyatakan ide; (5) dapat menghargai manfaat matematika bagi kehidupan; (6) bersikap dan berperilaku sesuai norma-norma dalam matematika maupun dalam proses pembelajarannya; (7) mengaplikasikan wawasan terhadap matematika pada kegiatan motorik yang dilakukan; (8) pada saat melakukan kegiatan matematika, siswa dapat mengoperasikan alat peraga sederhana dan hasil teknologi (Permendikbud, 2014).

Permendikbud No. 23 tahun 2016 revisi tentang standar penilaian pendidikan mendefinisikan Ketuntasan Belajar Minimal (KBM) sebagai ketuntasan belajar yang ditetapkan setiap satuan pendidikan. Akibatnya, pencapaian semua siswa di masing-masing satuan pendidikan diharapkan berada pada batas KBM yang telah ditentukan oleh satuan pendidikan. Namun faktanya, masih ada siswa yang kesulitan mencapai tujuan pembelajaran sehingga berdampak pada tidak tercapainya hasil belajar sesuai KBM yang ditetapkan. Berdasarkan data dari guru matematika, diketahui bahwa hasil belajar matematika siswa kelas VIII.6 SMP Negeri 16 Pekanbaru masih banyak yang belum mencapai KBM. KBM yang ditetapkan oleh SMP Negeri 16 Pekanbaru untuk mata pelajaran matematika adalah 75 . Dari 29 orang siswa hanya 3 orang siswa yang mencapai Ketuntasan Belajar Minimal (KBM) dengan persentase $10,34 \%$ pada materi pokok teorema pythagoras pada semester genap tahun pelajaran 2018/2019. Hal ini menunjukkan adanya kesenjangan antara harapan dengan kenyataan.

Berdasarkan hasil pengamatan proses pembelajaran matematika di kelas VIII.6 SMP Negeri 16 Pekanbaru, pada kegiatan pendahuluan diawali dengan berdoa, kemudian guru berkomunikasi dengan siswa dengan memberikan salam dan menanyakan kehadiran siswa, guru hanya memberikan apersepsi yaitu mengaitkan materi yang dipelajari hari ini dengan materi yang sudah dipelajari pada pertemuan sebelumnya. Guru tidak menyampaikan tujuan pembelajaran pada siswa. Selain itu, guru juga tidak memberikan motivasi terkait materi pelajaran yang akan dipelajari. Hal ini menunjukkan kegiatan belajar mengajar yang dilakukan belum sesuai dengan ketentuan pada Permendikbud Nomor 22 Tahun 2016 yang menyatakan bahwa pada kegiatan awal guru harus menyampaikan tujuan pembelajaran yang akan dicapai serta membangkitkan motivasi siswa dan melakukan apersepsi serta menyampaikan cakupan kegiatan pembelajaran yang akan dilakukan secara garis besar.

Pada kegiatan inti, guru memberi penjelasan tentang materi pelajaran yang akan dipelajari. Dalam menjelaskan materi, siswa diberi kesempatan untuk bertanya jika ada yang tidak dimengerti, akan tetapi sebagian besar siswa hanya diam dan tidak menanggapi. Guru menjelaskan dengan metode ceramah. Siswa mendengarkan penjelasan guru tersebut. Siswa hanya menerima saja apa yang disampaikan guru. Pembelajaran cenderung didominasi oleh guru, hal ini menyebabkan siswa kurang aktif dalam proses pembelajaran. Setelah menjelaskan materi, siswa diberikan waktu untuk mencatat materi yang telah diajarkan yang ada di papan tulis kemudian dilanjutkan dengan memberikan soal latihan. Pada saat siswa mengerjakan soal latihan, hanya beberapa siswa yang aktif bertanya kepada guru dan fokus dalam mengerjakan soal, sedangkan siswa lainnya lebih memilih menunggu jawaban temannya yang sudah selesai dari pada mengerjakan soal latihan secara mandiri. Kondisi tersebut menunjukkan bahwa sebagian besar siswa tidak berminat mengikuti kegiatan pembelajaran dengan baik, akibat kurang memahami konsep dari materi pelajaran sehingga mereka tidak mengerjakan soal latihan secara mandiri. Mengacu pada Permendikbud Nomor 22 Tahun 2016 pada kegiatan inti guru seharusnya membelajarkan siswa menemukan, membentuk dan mengembangkan pengetahuan sendiri, guru hanya sebagai fasilitator bagi siswa untuk menemukan konsep dari materi yang diajarkan. Seharusnya pelaksanaan kegiatan inti menggunakan model pembelajaran, metode pembelajaran, media pembelajaran, dan sumber belajar disesuaikan dengan karakteristik siswa dan mata pelajaran.

Pada kegiatan penutup guru tidak menyimpulkan materi pelajaran dan guru langsung memberikan soal pekerjaan rumah 
kepada siswa. Kemudian pembelajaran diakhiri dengan doa dan salam. Seharusnya, menurut Permendikbud Nomor 22 Tahun 2016, pada kegiatan penutup guru bersama siswa membuat simpulan pelajaran, melakukan refleksi, umpan balik, tindak lanjut dan menyampaikan rencana pembelajaran pada pertemuan berikutnya

Peneliti melakukan wawancara mengenai permasalahan yang dihadapi guru selama proses pembelajaran. Berdasarkan informasi dari hasil wawancara kepada guru bidang studi Matematika terhadap siswa kelas VIII.6 SMP Negeri 16 Pekanbaru didapatkan informasi bahwa: (1) siswa kurang aktif dalam proses pembelajaran matematika; (2) dominasi siswa yang berkemampuan tinggi sangat jelas; (3) kurangnya rasa ingin tahu siswa; (4) siswa kurang berdiskusi dan bekerja sama antar siswa; dan (5) penguasaan materi kurang. Hal ini menyebabkan terjadinya kesenjangan dalam pembelajaran, dimana tidak meratanya penyebaran pengalaman belajar di antara siswa. Selain itu, dalam pembelajaran guru tidak menggunakan model pembelajaran yang inovatif, guru juga belum menggunakan LKS yang dibuatnya sendiri. Permasalahanpermasalahan tersebut berdampak pada hasil belajar siswa kelas VIII.6 SMP Negeri 16 Pekanbaru.

Berdasarkan observasi dan wawancara peneliti dengan guru bidang studi tersebut, peneliti menyimpulkan bahwa perlu adanya perbaikan dari proses pembelajaran agar hasil belajar matematika siswa dapat meningkat. Peneliti memandang perlu diberikan suatu model pembelajaran yang dapat mendorong siswa untuk aktif dalam pembelajaran dan mengoptimalkan partisipasi siswa dalam kelompok. Oleh sebab itu, perlu dilaksanakan suatu model pembelajaran yang melibatkan peran siswa secara aktif dalam kegiatan belajar mengajar, guna meningkatkan hasil belajar matematika siswa maka perlu diterapkan suatu model pembelajaran yang interaktif, menantang, memotivasi siswa, membantu siswa untuk berkomunikasi, mencerna, memecahkan masalah untuk membentuk pengetahuannya sendiri, dan mengembangkan kegiatan siswa untuk mengkomunikasikan gagasan dalam memecahkan masalah matematika untuk meningkatkan hasil belajar matematika siswa.
Salah satunya dengan cara penerapan pembelajaran kooperatif.

Di dalam model pembelajaran kooperatif terdapat berbagai teknik atau pendekatan untuk menerapkan pembelajaran tersebut, salah satunya adalah pendekatan struktural Numbered Heads Together (NHT). Model pembelajaran kooperatif pendekatan struktural NHT ini lebih menekankan pada pola interaksi siswa yang bertujuan untuk meningkatkan penguasaan akademik setiap siswa. Kemudian memberikan kesempatan kepada siswa dan meningkatkan semangat kerja sama, memberikan suasana baru bagi siswa karena semuanya diikut sertakan dalam proses pembelajaran dan mereka tidak mengetahui siapa diantara mereka yang akan mempresentasi hasil pekerjaan mereka di depan kelas, sehingga semuanya dituntut agar dapat memahami dan menguasai semua tujuan pembelajaran yang harus dicapai pada proses pembelajaran tersebut. Menurut Hill (Trianto, 2007) kelebihan dari model pembelajaran Kooperatif NHT yaitu siswa dapat mengemukakan pemikirannya dengan bertukar pendapat, saling bekerja sama jika ada teman kelompoknya yang mengalami kesulitan, dapat meningkatkan prestasi belajar, mampu memperdalam pamahaman siswa, menyenangkan siswa dalam belajar, mengembangkan sikap positif dan sikap kepemimpinan, mengembangkan rasa ingin tahu, meningkatkan rasa percaya diri, mengembangkan rasa saling memiliki, serta mengembangkan keterampilan untuk masa depan. Adapun kekurangannya yaitu membutuhkan waktu yang cukup lama bagi siswa dan guru dalam pelaksanaan pembelajaran.

Menilik paparan di atas, peneliti berkesimpulan bahwa guna memperbaiki proses pembelajaran dan meningkatkan pencapaian siswa, peneliti perlu menggunakan model pembelajaran kooperatif pendekatan struktural NHT di kelas VIII.6 SMP Negeri 16 Pekanbaru semester genap tahun pelajaran 2018/2019 pada kompetensi dasar 3.9 membedakan dan menentukan luas permukaan dan volume bangun ruang sisi datar (kubus, balok, prisma, dan limas), dan 4.9 menyelesaikan masalah yang berkaitan dengan luas permukaan dan volume bangun ruang sisi 
datar (kubus, balok, prima dan limas), serta gabungannya.

\section{METODE}

Bentuk penelitian merupakan penelitian tindakan kelas (PTK) kolaboratif, dimana peneliti bekerjasama dengan guru matematika yang bertugas di kelas VIII.6 SMP Negeri 16 Pekanbaru. Menurut Arikunto, dkk (2012), Penelitian tindakan kelas dilaksanakan melalui empat tahap dalam satu siklus, yaitu (1) perencanaan; (2) pelaksanaan; (3) pengamatan; dan (4) refleksi. Penelitian ini dilakukan dalam dua siklus. Penerapan model pembelajaran kooperatif pendekatan struktural Numbered Heads Together (NHT) dipilih sebagai usaha yang dilakukan untuk memperbaiki kegiatan belajar mengajar pada penelitian ini.

Jumlah subjek penelitian ini sebanyak 29 orang siswa meliputi 13 orang siswa laki-laki dan 16 orang siswa perempuan yang berasal dari kelas VIII.6 SMP Negeri 16 Pekanbaru tahun ajaran 2018/2019. Instrumen penelitian merupakan perangkat pembelajaran yang terdiri dari silabus, rencana pelaksanaan pembelajaran (RPP) dan lembar kerja siswa (LKS). Instrumen pengumpulan data yaitu lembar observasi aktivitas guru dan siswa dan soal tes hasil belajar matematika.

Teknik analisis data yang dilakukan dalam penelitian ini adalah sebagai berikut;

1. Analisis Data Aktivitas Guru dan Siswa

Setelah kegiatan belajar mengajar di setiap pertemuan selesai, pengamat dan peneliti mendiskusikan dan menganalisis hasil observasi hari itu untuk menemukan kelebihan dan kekurangan dalam pelaksanaan proses pembelajaran yang dilakukan peneliti. Apabila terdapat kelemahan atau kekurangan perlu adanya usaha perbaikan atau tindakan yang dilakukan pada saat pembelajaran pada pertemuan selanjutnya.

\section{Analisis Data Hasil Belajar Matematika}

Data tentang hasil belajar matematika yang diperoleh dari ulangan harian dianalisis berdasarkan nilai perkembangan dan ketercapaian KBM.

a. Analisis Nilai Perkembangan Individu Siswa dan Penghargaan Kelompok

Nilai perkembangan individu siswa ditentukan di setiap akhir siklus. Pada siklus I, nilai perkembangan ini diperoleh dengan menentukan selisih nilai skor dasar dengan nilai ulangan harian I siswa. Sementara, pada siklus II, nilai perkembangan dapat dihitung dengan menentukan selisih nilai ulangan harian I dengan nilai ulangan harian II.

Tabel 1. Nilai Perkembangan Individu

\begin{tabular}{lc}
\hline \multicolumn{1}{c}{ Skor peniaian } & $\begin{array}{c}\text { Nilai } \\
\text { Perkembangan }\end{array}$ \\
\hline $\begin{array}{l}\text { nilai yang lebih dari 10 } \\
\text { poin di bawah skor } \\
\text { dasar }\end{array}$ & 5 \\
$\begin{array}{l}\text { Nilai yang 10 poin } \\
\text { hingga 1 poin di bawah } \\
\text { skor dasar }\end{array}$ & 10 \\
$\begin{array}{l}\text { Nilai yang sama dengan } \\
\text { skor dasar sampai 10 } \\
\text { poin di atas skor dasar }\end{array}$ & 20 \\
$\begin{array}{l}\text { Lebih dari 10 poin di } \\
\text { atas skor dasar }\end{array}$ & 30 \\
$\begin{array}{l}\text { Nilai sempurna (tidak } \\
\text { berdasarkan skor dasar) }\end{array}$ & 30 \\
\hline
\end{tabular}

Sumber: Slavin (2010)

Dalam menentukan penghargaan kelompok, peneliti menentukan rata-rata nilai perkembangan yang diperoleh setiap anggota kelompok tersebut. Rata-rata nilai perkembangan kelompok tersebut kemudian disesuai dengan kriteria penghargaan kelompok yang digunakan.

Tabel 2. Kriteria Penghargaan Kelompok

\begin{tabular}{cc}
\hline $\begin{array}{c}\text { Rata-Rata Nilai } \\
\text { Perkembangan } \\
\text { Kelompok }\end{array}$ & $\begin{array}{c}\text { Penghargaan } \\
\text { Kelompok }\end{array}$ \\
\hline $5 \leq \bar{x} \leq 15$ & Baik \\
$15 \leq \bar{x} \leq 25$ & Hebat \\
$25 \leq \bar{x} \leq 30$ & Super \\
\hline
\end{tabular}

Sumber : Slavin (2010)

\section{b. Analisis Ketercapaian KBM}

Ketercapaian KBM dianalisis dengan membandingkan besaran persentase siswa yang mencapai KBM pada skor awal dengan siswa yang mencapai KBM pada tes hasil belajar matematika setelah pembelajaran kooperatif pendekatan struktural NHT diterapkan. Bersandar pada rumus yang disampaikan Aqib (2010), peneliti menggunakan formula berikut untuk menentukan persentase siswa yang mencapai KBM pada skor awal, ulangan harian I, dan ulangan harian II. 


$$
P S=\frac{J s}{J k} \times 100 \%
$$

Keterangan :

Ps = Persentase siswa yang mencapai KBM

Js = Jumlah siswa yang mencapai KBM

$\mathrm{Jk}=$ Jumlah siswa

c. Analisis Ketercapaian KBM Indikator Untuk melihat tingkat ketercapaian KBM di masing-masing indikator, peneliti melakukan analisis ketercapaian indikator. Analisis data ketercapaian indikator dapat dilihat melalui hasil belajar matematika siswa secara individu yang diperoleh dari ulangan haria I dan ulangan harian II. Siswa dikatakan tuntas pada setiap indikator jika telah mencapai nilai $\geq 75$. Ketercapaian KBM indikator dihitung dengan menentukan besarnya persentase siswa yang mencapai KBM di masing-masing indikator. Rumus yang digunakan untuk menghitung ketercapaian KBM di masing-masing indikator mengacu pada rumus yang disampaikan Purwanto (2011) yaitu:

$\mathrm{KI}=\frac{\mathrm{SS}}{\mathrm{SM}} \times 100 \%$.

Keterangan : $\quad \mathrm{KI}$ : ketercapaian indikator SS : skor yang diperoleh siswa SM : skor maksimum

\section{HASIL DAN PEMBAHASAN}

Pelaksanaan kegiatan pembelajaran dengan pembelajaran kooperatif pendekatan struktural NHT sudah sesuai dengan apa yang direncanakan dan proses pembelajaran yang diharapkan. Berdasarkan hasil analisis aktivitas guru dan siswa di setiap pertemuan terlihat dari pelaksanaan proses semakin minimnya kekurangan dan kelemahan yang terjadi pada siklus II dibandingkan dengan kekurangan dan kelemahan yang terjadi pada siklus I.

Pada pelaksanaan tindakan dari siklus I ke siklus II, aktivitas guru semakin sesuai dengan perencanaan dan siswa juga sudah semakin terbiasa dengan pembelajaran yang diterapkan guru. Siswa telah memiliki kesadaran dan bersungguh-sungguh dalam mengerjakan tugasnya (LKS), pada tahap diskusi kelompok, tiap anggota kelompok ikut berpartisipasi aktif dalam mengerjakan tugasnya (LKS) dan pada tahap evaluasi, siswa yang nomornya dipanggil untuk mempresentasikan hasil diskusi kelompok bertanggung jawab dalam mempresentasikan nomor soal yang didapatnya. Siswa yang lainnya juga semakin aktif dalam memberikan tanggapan kepada kelompok penyaji. Berdasarkan hal ini, dapat dikatakan bahwa penerapan model pembelajaran kooperatif pendekatan struktural NHT yang diterapkan di kelas VIII.6 SMP Negeri 16 Pekanbaru dapat meningkatkan kualitas pembelajaran.

Untuk menganalisis hasil belajar siswa, peneliti melakukan analisis terhadap nilai perkembangan individu siswa, penghargaan kelompok, pencapaian KBM di setiap indikator, dan pencapaian KBM secara keseluruhan. Tabel 3 berikut menyajikan data nilai perkembangan siswa untuk siklus I dan siklus II.

Tabel 3. Nilai Perkembangan Individu Siswa pada Siklus I dan Siklus II

\begin{tabular}{|c|c|c|c|c|}
\hline No & Skor Tes & $\begin{array}{c}\text { Poin } \\
\text { Kemajuan }\end{array}$ & $\begin{array}{l}\text { Jumlah } \\
\text { Siswa } \\
\text { (Siklus } \\
\text { I) } \\
\end{array}$ & $\begin{array}{c}\text { Jumlah } \\
\text { Siswa } \\
\text { (Siklus } \\
\text { II) } \\
\end{array}$ \\
\hline 1 & $\begin{array}{l}\text { Lebih dari } \\
10 \text { poin di } \\
\text { bawah skor } \\
\text { awal }\end{array}$ & 5 & 7 siswa & 2 siswa \\
\hline 2 & $\begin{array}{l}\text { Antara } 10 \\
\text { sampai } 1 \\
\text { poin di } \\
\text { bawah skor } \\
\text { awal }\end{array}$ & 10 & 8 siswa & 2 siswa \\
\hline 3 & $\begin{array}{l}\text { Sama } \\
\text { dengan skor } \\
\text { dasar } \\
\text { sampai } 10 \\
\text { poin di atas } \\
\text { skor awal }\end{array}$ & 20 & 4 siswa & 2 siswa \\
\hline 4 & $\begin{array}{l}\text { Lebih dari } \\
10 \text { poin di } \\
\text { atas skor } \\
\text { awal }\end{array}$ & 30 & 8 siswa & 9 siswa \\
\hline 5 & $\begin{array}{l}\text { Kertas } \\
\text { jawaban } \\
\text { sempurna } \\
\text { (terlepas } \\
\text { dari skor } \\
\text { awal) }\end{array}$ & 30 & 2 siswa & 11 siswa \\
\hline
\end{tabular}

Sumber: Olah data peneliti

Berdasarkan Tabel 3 terlihat bahwa jumlah siswa mengalami peningkatan nilai perkembangan individu siswa pada siklus II. Artinya, setelah diterapkannya model pembelajaran kooperatif pendekatan struktural NHT, pecapaian matematika siswa menjadi meningkat. Hal ini dilihat dari hasil analisis 
nilai perkembangan individu yang didasarkan pada kriteria peningkatan hasil belajar.

Tabel 4. Persentase Ketercapaian KBM

\begin{tabular}{lccc}
\hline \multirow{2}{*}{ Keterangan } & \multicolumn{3}{c}{ Frekuensi Siswa } \\
\cline { 2 - 4 } & $\begin{array}{c}\text { Skor } \\
\text { Dasar }\end{array}$ & $\begin{array}{c}\text { Skor } \\
\text { UH-I }\end{array}$ & $\begin{array}{c}\text { Skor } \\
\text { UH-II }\end{array}$ \\
\hline $\begin{array}{l}\text { Jumlah Siswa } \\
\text { mencapai KKM }\end{array}$ & 3 & 5 & 14 \\
$\begin{array}{l}\text { Persentase siswa } \\
\text { mencapai KKM }\end{array}$ & $10,34 \%$ & $17,24 \%$ & $48,27 \%$ \\
\hline $\begin{array}{l}\text { Sumber: Olah data peneliti } \\
\text { Sumb }\end{array}$ & &
\end{tabular}

Tabel 4 menunjukkan bahwa terjadi peningkatan jumlah siswa yang mencapai KBM dari skor dasar (sebelum tindakan) ke nilai $\mathrm{UH}$ I (sesudah tindakan) serta adanya peningkatan hasil belajar UH I ke UH II (setelah tindakan).

Tabel 5. Persentase Persentase Ketercapaian KBM Setiap Indikator Pada UH-I

\begin{tabular}{clcc}
\hline No & $\begin{array}{c}\text { Indikator } \\
\text { Ketercapaian }\end{array}$ & $\begin{array}{c}\text { Siswa } \\
\text { mencapai } \\
\text { KBM }\end{array}$ & $\begin{array}{c}\text { \% Siswa } \\
\text { mencapai } \\
\text { KBM }\end{array}$ \\
\hline 1 & $\begin{array}{l}\text { Menghitung } \\
\text { luas permukaan } \\
\text { balok dan kubus } \\
\text { Menyelesaikan } \\
\text { masalah luas } \\
\text { permukaan } \\
\text { balok dan kubus } \\
\text { Menghitung }\end{array}$ & 29 & $100 \%$ \\
\hline $\begin{array}{l}\text { volume balok } \\
\text { dan kubus } \\
\text { Menyelesaikan } \\
\text { masalah volume } \\
\text { dan kubus }\end{array}$ & 5 & $10,34 \%$ \\
\hline 5 & $\begin{array}{l}\text { Menghitung } \\
\text { luas permukaan } \\
\text { prisma } \\
\text { Menyelesaikan } \\
\text { masalah luas } \\
\text { permukaan } \\
\text { prisma }\end{array}$ & 2 & $20,69 \%$ \\
\hline Sumber $:$ Olah data peneliti & & \\
\hline
\end{tabular}

Sumber : Olah data peneliti

Tabel 5 diatas menunjukkan bahwa tidak semua siswa mencapai KBM pada setiap indikator, peneliti menyimpulkan bahwa penyebab dari banyaknya siswa yang tidak mencapai KBM karena siswa belum dapat memahami soal dengan baik, salah menggunakan rumus dan siswa tidak mengerjakan soal. Banyaknya siswa yang tidak mencapai KBM ini juga disebabkan kelemahan peneliti yaitu peneliti kurang memberikan contoh soal yang lebih banyak sehingga siswa terbiasa dengan soal-soal yang tergolong mudah.
Tabel 6. Persentase Ketercapaian KBM Indikator Pada UH-II

\begin{tabular}{|c|c|c|c|}
\hline No & $\begin{array}{c}\text { Indikator } \\
\text { Ketercapaian }\end{array}$ & $\begin{array}{c}\text { Siswa } \\
\text { mencapai } \\
\text { KBM }\end{array}$ & $\begin{array}{c}\text { \% Siswa } \\
\text { mencapai } \\
\text { KBM }\end{array}$ \\
\hline 1 & $\begin{array}{l}\text { Menghitung } \\
\text { volume prisma }\end{array}$ & 29 & $100 \%$ \\
\hline 2 & $\begin{array}{l}\text { Menyelesaikan } \\
\text { masalah } \\
\text { volume prisma }\end{array}$ & 3 & $10,34 \%$ \\
\hline 3 & $\begin{array}{l}\text { Menghitung } \\
\text { luas } \\
\text { permukaan } \\
\text { limas }\end{array}$ & 14 & $48,27 \%$ \\
\hline 4 & $\begin{array}{l}\text { Menyelesaikan } \\
\text { masalah } \\
\text { tentang } \\
\text { permukaan } \\
\text { limas }\end{array}$ & 0 & $0 \%$ \\
\hline 5 & $\begin{array}{l}\text { Menghitung } \\
\text { volume limas }\end{array}$ & 11 & $37,93 \%$ \\
\hline 6 & $\begin{array}{l}\text { Menyelesaikan } \\
\text { masalah } \\
\text { tentang } \\
\text { volume limas }\end{array}$ & 0 & $0 \%$ \\
\hline
\end{tabular}

Tabel 6 menunjukkan bahwa tidak semua siswa yang mencapai KBM pada setiap indikator. Berdasarkan analisis yang dilakukan peneliti terhadap hasil belajar siswa pada ulangan harian II, kesalahan terjadi karena siswa kesulitan memahami konsep, dan salah dalam melakukan operasi hitung.

\section{SIMPULAN}

Berdasarkan penelitian yang telah peneliti lakukan, peneliti berkesimpulan bahwa dengan menerapkan pembelajaran kooperatif pendekatan struktural Numbered Heads Together (NHT) dapat meningkatkan mutu kegiatan pembelajaran dan meningkatkan hasil belajar matematika siswa di kelas VIII.6 SMP Negeri 16 Pekanbaru pada semester genap tahun ajaran 2018/2019 pada materi bangun ruang untuk kompetensi dasar (3.9) membedakan dan menentukan luas permukaan dan volume bangun ruang sisi datar (kubus, balok, prisma, dan limas) dan (4.9) menyelesaikan masalah yang berkaitan dengan luas permukaan dan volume bangun ruang sisi datar (kubus, balok, prisma, dan limas) serta gabungannya. 
Volume 2, Nomor 2, Mei 2020

DOI: https://doi.org/10.33578/prinsip.v2i2.54

jprinsip.ejournal.unri.ac.id

\section{REKOMENDASI}

Untuk meningkatkan pencapaian belajar matematika siswa, model pembelajaran kooperatif pendekatan struktural Numbered Heads Together (NHT) dapat dipertimbangkan untuk diterapkan baik oleh guru dalam menjalankan tugasnya mengajar dan mendidik siswa maupun oleh peneliti yang ingin melakukan penelitian.

\section{DAFTAR PUSTAKA}

Aqib, Z. (2010). Penelitian tindakan kelas. Yrama Widya

Arikunto, S., Suhardjono, \& Supardi. (2012). Penelitian tindakan kelas. Bumi Aksara

Kemendikbud. (2014). Salinan Lampiran Permendikbud No. 58 Tahun 2014 Tentang Kurikulum 2013 Sekolah Menengah Pertama/Madrasah Tsanawiyah. Kemendikbud
Kemendikbud. (2016). Salinan Lampiran Permendikbud No. 22 Tentang Standar Proses Pendidikan Dasar dan Menengah. Kemendikbud

Kemendikbud. (2016). Salinan Lampiran Permendikbud No. 23 Tentang Standar Penilaian Pendidikan. Kemendikbud.

Purwanto. (2011). Evaluasi hasil belajar. Pustaka Pelajar.

Slavin. (2010). Cooperative Learning teori, riset dan praktis. Allyn dan Bacon

Trianto. (2011). Model-model pembelajaran inovatif berorientasi konstruktivistik. Prestasi Pustaka 